\title{
Pemanfaatan Model-model dalam Pelayanan Konseling untuk Membentuk Generasi Berkarakter Bebas Narkoba
}

Fadilla Yusri

Universitas Negeri Padang

\section{Abstract}

One of the unsettling society not only in Indonesia but also in the rest of the world is the circulation of drugs, especially among students. Not only consume, nowadays there are also students and the young generation which helped distribution, ranging from airport to the courier. Drug abuse is a social problem that always comes up in the midst of the community. Drug circulation increasingly bolder worrying; drugs became one of the nation's character Assassin. Indonesia was in a crisis of character. The spread of drug prevention efforts among the younger generation is supposed to be a shared responsibility, in this case all parties including parents, teachers, and the public should be aware of are active in contributing to the threat of drugs towards the younger generation. One way is to establish and improve the character of the young generation is by providing help through counseling. Counseling counselor should be done through a clear procedure, so that the process happens more effectively and right on target. Counselling is not solely the verbal sentence formulation, but also load the roles that run by counsellors and clients, the procedure is, and the behavior of clients that will be transformed in the process. Because of that in providing services to the client whether or not there are nine Sha-counseling model that can be used by counselors.

Keyword: Karakter, Narkoba, dan Model konseling

Copyright @ 2014 IICE - Multikarya Kons (Padang - Indonesia) dan IKI - Ikatan Konselor Indonesia - All Rights Reserved Indonesian Institute for Counseling and Education (IICE) Multikarya Kons

\section{PENDAHULUAN}

Masih lekat rasanya dalam ingatan kita nama Zarima si ratu ekstasi, yang sekarang sudah menghirup udara kebebasannya kembali. Baru-baru ini santer lagi diperbincangkan si ratu mariyuana Corby, yang juga mendapatkan grasi dan sekarang sudah diberikan bebas bersyarat. Mungkin masih banyak lagi deretan nama-nama yang telah membawa barang haram itu ke negeri kita tercinta ini. Hingga kini penyebaran penyalahgunaan narkoba sudah hampir tak bisa dicegah. Mengingat hampir seluruh penduduk dunia bisa dengan mudah mendapat narkoba dari oknum-oknum yang tidak bertanggung jawab. Tentu saja hal ini bisa membuat orang tua, organisasi masyarakat, dan pemerintah khawatir.

Tidak dapat dipungkiri bahwa narkoba merupakan wabah paling berbahaya yang menjangkiti manusia di seluruh pelosok bumi. Tidak diragukan lagi, bahwa kelemahan iman dan jauhnya diri dari Allah merupakan faktor terpenting yang membawa kita masuk ke dalam lingkungan narkoba. Manusia yang taat beragama pasti akan jauh dari neraka narkoba. Tidak mungkin dia akan mengulurkan tangannya pada narkoba, baik membeli, mengedarkan, maupun menyelundupkannya. Sebab, jalan narkoba adalah jalan setan dan jalan Allah tidak mungkin bertemu dengan jalan setan.

Di Indonesia, pencandu narkoba ini perkembangannya semakin pesat, para pencandu narkoba pada umumnya berusia antara 11 sampai 24 tahun, artinya usia tersebut ialah usia produktif atau usia pelajar, pada 
awalnya pelajar yang mengonsumsi narkoba biasanya mereka yang sudah mengenal rokok, karena kebiasaan merokok sepertinya sudah menjadi hal yang wajar di kalangan pelajar saat ini. Jumlah pengguna narkotika dan obat-obat terlarang akan semakin bertambah bila kita tidak melakukan upaya pencegahan sejak dini. Hingga 2012 ini tercatat jumlah pengguna narkotika dan obat terlarang mencapai 5 juta orang.

Maraknya narkotika dan obat-obatan terlarang telah banyak mempengaruhi mental dan sekaligus pendidikan bagi para pelajar saat ini. Masa depan bangsa yang besar ini bergantung sepenuhnya pada upaya pembebasan kaum muda dari bahaya narkoba. Narkoba telah menyentuh lingkaran yang semakin dekat dengan kita semua. Teman dan saudara kita mulai terjerat oleh narkoba yang sering kali dapat mematikan. Sebagai makhluk Tuhan yang kian dewasa, seharusnya kita senantiasa berfikir jernih untuk menghadapi globalisasi teknologi dan globalisasi yang berdampak langsung pada keluarga dan remaja penerus bangsa khususnya. Kita harus memerangi kesia-siaan yang di akibatkan oleh narkoba.

Narkoba merupakan obat-obatan yang mengandung unsur dan zat-zat addictive. Jika sudah pernah mencicipi kenikmatan yang disuguhkan oleh obat terlarang ini, maka akan sulit untuk menghentikan konsumsinya. Mirip dengan bagaimana orang bisa kecanduan rokok, alkohol, atau bahkan kecanduan bermain game. Bagaimanapun juga, sesuatu yang terlalu berlebihan tidak pernah menjadi sesuatu yang baik. Namun, sangat sulit untuk membuat orang yang sudah kecanduan untuk berhenti dan menjadi normal kembali.

Jika hal tersebut ada pada diri anak-anak di bawah umur, yaitu anak-anak yang belum dewasa dan masih memerlukan bimbingan, maka sudah menjadi tugas orang tua dan guru serta seluruh masyarakat yang lebih tua dan lebih mengerti mana yang baik, dan mana yang buruk untuk senantiasa memperingatkan dan membimbing anak-anak tersebut supaya tidak semakin terjerumus. Mereka memerlukan bantuan dari orang lain.

Pemakaian narkoba pada tahap awal akan menyebabkan perasaan enak, tetapi pada pemakaian selanjutnya akan menimbulkan kerusakan organ tubuh, kerusakan mental dan bahkan menyebabkan kematian. Jika pemakai narkoba tersebut adalah remaja atau bahkan anak-anak maka akan berakibat rusaknya mental remaja sebagai generasi penerus bangsa. Rusaknya generasi penerus berakibat runtuhnya suatu bangsa/negara. Pada dasarnya orang memilih lari ke narkoba karena tak mampu menyelesaikan masalah hidup yang mendatanginya dengan baik.

Hurlock (1980:224) menyebutkan bahwa yang membuat remaja mulai menggunakan obat-obatan adalah karena terdorong untuk membebaskan diri dari segala larangan keluarga, karena ingin untuk menambah dukungan sosial kelompoknya dengan jalan menyesuaikan diri dengan pola perilaku yang ditetapkan oleh pemimpinnya, atau karena ingin untuk berpetualang. Dalam banyak kasus misalnya, pecandu narkoba yang masih di bawah umur mulai mengkonsumsi narkoba karena kekurangan teman bicara serta kurangnya kepercayaan pada sesama manusia terutama orang dewasa seperti orang tua dan guru.

Dalam membantu penyembuhan pecandu narkoba, bimbingan konseling diberikan tidak hanya kepada pecandu namun juga keluarganya. Hal ini karena keadaan psikis dan mental pecandu sudah sangat rapuh sehingga perlu dukungan dari berbagai pihak supaya pecandu tersebut bisa lepas sepenuhnya dari narkoba dan tidak mencoba mengkonsumsi obat-obatan tersebut yang bisa menyebabkan kambuhnya masalah kecanduan yang sama.

Konseling bagi korban penyalahguna/ketergantungan NAPZA menurut Depsos (2004), merupakan hubungan antara konselor dengan pecandu Narkotika, Alkohol, Psikotropika dan Zat Adiktif lainnya yang selanjutnya disingkat dengan NAPZA, dalam rangka membantu meningkatkan kesadaran akan masalah yang dialaminya serta potensi-potensi atau kekuatan-kekuatannya yang akan digunakan dalam melakukan perubahan perilaku, untuk mengatasi kesulitan dan menentu- kan keputusan.

Konseling terhadap pecandu narkoba tidak bisa dilakukan oleh sembarang orang, harus dilakukan oleh seorang konselor yang telah ahli di bidang konseling. Konselor dalam melakukan pekerjaannya membimbing si pecandu pun harus memegang teguh beberapa prinsip (menerima, memiliki empati, tulus, tidak menghakimi, berpikir secara rasional, dan lain sebagainya), supaya kegiatan konseling bisa terkondisikan dengan baik. Konseling yang baik memerlukan kerjasama dari berbagai pihak. Intinya adalah saling memahami dan saling mendukung supaya pecandu bisa sembuh dari efek buruk narkoba. 


\section{NARKOBA}

Perkembangan narkoba berawal sejak tahun 2737 SM ketika Kaisar Cina bernama Shen Nung menulis naskah farmasi yang bernama Pen Tsao atau "Ramuan Hebat" (Great Herbal). Salah satu ramuan itu adalah disebut liberator of sin atau delight giver (pemberi kesenangan) yang ditujukan untuk kesenangan, obat lemah badan, malaria, rematik, dan analgesik (Martin, 1977 dalam Dadang Hawari, 2002).

Pada tahun 800 SM di India ditemukan ramuan sejenis opium yang disebut the heavenly guide, digunakan oleh masyarakat sebagai pemberi kesenangan (fly) dan juga sebagai anti sakit (analgesik). Opium banyak pula ditemukan di Cina, Mesir, Turki, dan segitiga emas (Kamboja, Vietnam, Thailand). Pada tahun 1973 atau 2500 tahun kemudian ditemukan antara lain di India, Cina, dan Amerika Selatan, sejenis obat (drug) yang saat ini amat populer yaitu marijuana yang berasal dari tanaman linneaeus canabis sativa. Suku-suku primitif seperti Aztec dan suku-suku di banyak negara Amerika Selatan (Latin) menggunakan ramuan-ramuan hallucinogenic seperti marijuana dan sejenisnya untuk upacara-upacara ritual kepercayaannya mendekati roh-roh, dan untuk bahan analgesik (Kisker, 1977; Martin, 1977 dalam Dadang Hawari, 2002).

Narkoba merupakan singkatan dari Narkotika dan Obat-obat berbahaya yang telah popular beredar dimasyarakat perkotaan maupun di perdesaan, termasuk bagi aparat hukum. Selain Narkoba, istilah lain yang diperkenalkan khususnya oleh Departemen Kesehatan RI adalah NAPZA yaitu singkatan dari Narkotika, Pasikotropika dan Zat adiktif lainnya. Semua istilah ini sebenarnya mengacu pada sekelompok zat yang umumnya mempunyai risiko yang oleh masyarakat disebut berbahaya yaitu kecanduan (adiksi).

Semua istilah ini, baik "narkoba" ataupun "napza", mengacu pada kelompok senyawa yang umumnya memiliki risiko kecanduan bagi penggunanya. Narkoba atau NAPZA merupakan bahan/zat yang bila masuk ke dalam tubuh akan mempengaruhi tubuh terutama susunan syaraf pusat/otak sehingga bilamana disalahgunakan akan menyebabkan gangguan fisik, psikis/jiwa dan fungsi sosial. Karena itu Pemerintah memberlakukan UndangUndang untuk penyalahgunaan narkoba yaitu UU No.5 tahun 1997 tentang Psikotropika dan UU No.22 tahun 1997 tentang Narkotika.

Menurut Kurniawan (2008) adalah zat kimia yang dapat mengubah keadaan psikologi seperti perasaan, pikiran, suasana hati serta perilaku jika masuk ke dalam tubuh manusia baik dengan cara dimakan, diminum, dihirup, suntik, intravena, dan lain sebagainya. Menurut Soerdjono Dirjosisworo mengatakan bahwa narkotika adalah "Zat yang bisa menimbulkan pengaruh tertentu bagi yang menggunakannya dengan memasukkan kedalam tubuh. Pengaruh tersebut bisa berupa pembiusan, hilangnya rasa sakit, rangsangan semangat dan halusinasi atau timbulnya khayalan-khayalan. Sifat-sifat tersebut yang diketahui dan ditemukan dalam dunia medis bertujuan dimanfaatkan bagi pengobatan dan kepentingan manusia di bidang pembedahan, menghilangkan rasa sakit dan lain-lain.

Narkotika adalah zat atau obat yang berasal dari tanaman atau bukan tanaman baik sintetis maupun semisintetis yang akan menyebabkan perubahan kesadaran, mengurangi sampai menghilangkan rasa sakit dan dapat menimbulkan ketergantungan (adiksi). Jenis narkotika yang sering disalahgunakan adalah morfin, heroin (putauw), petidin, termasuk ganja atau kanabis, mariyuana, hashis, kokain, tanaman papaver, opium mentah, opium masak (candu, jicing, jicingko), opium obat, ekgonina. Zat-zat tersebut dapat membuat berbagai efek samping seperti Halusinasi, ketagihan, dan efek psikologi lainnya. Cara penggunaan bisa melalui suntikan, dimakan, dihisap, atau dihirup. Contoh zat-zat berbahaya yang dikonsumi dengan cara dihisap adalah Opium yang menggunakan pipa hisapan.

Golongan psikotropika adalah zat atau obat baik alami maupun sintetis namun bukan narkotika yang berkhasiat aktif terhadap kejiwaan (psikoaktif) melalui pengaruhnya pada susunan syaraf pusat sehingga menimbulkan perubahaan tertentu pada aktivitas mental dan perilaku. Jenis Psikotropika yang sering disalahgunakan adalah amfetamin, ekstasi, shabu, obat penenang seperti mogadon, rohypnol, dumolid, lexotan, pil koplo, BK, termasuk LSD, Mushroom. Zat adiktif lainnya disini adalah bahan/zat bukan Narkotika \& Psikotropika seperti alkohol/etanol atau metanol, tembakau, gas yang dihirup (inhalansia) maupun zat pelarut (solven).

Beberapa hal yang perlu di ketahui tentang narkotika, psikotropika, dan bahan adiktif, ketiganya berasal dari bahan yang berbeda dan memiliki dampak yang berbeda, ketiganya juga kerap menjadi perdagangan terselubung yang korbannya tidak lain anak-anak yang belum memiliki pengetahuan mengenai narkoba. Berawal 
dari menghisap rokok, anak dan remaja yang mempunyai rasa ingin tahu yang besar dan mencoba sesuatu yang baru maka ia akan beralih pada zat lain yang akan memberikan sensasi dan kenikmatan yang lebih, yaitu narkoba.

Berkembangnya jumlah pecandu narkoba ditentukan oleh dua faktor, yaitu faktor dalam dan di luar diri sendiri. Faktor penentu dalam diri menurut Hurlock (1980) adalah: (1) minat, (2) rasa ingin tahu (curiousity) (3) lemahnya rasa ketuhanan, dan (4) ketakstabilan emosi. Sedangkan, faktor-faktor yang berasal dari luar diri sendiri adalah: (1) gangguan psikososial keluarga, (2) lemahnya hukum terhadap pengedar dan pengguna narkoba, (3) lemahnya sistem sekolah termasuk bimbingan dan konseling (BK), serta yang terpenting (4) lemahnya pendidikan agama para siswa sekolah.

Secara keseluruhan obat-obatan ini dapat menimbulkan gangguan-gangguan pada sistem saraf manusia, juga pada organ-organ tubuh manusia. Narkoba juga akan mengakibatkan kecanduan/ketagihan kepada pemakainya dan apabila pemakaian dihentikan, dapat mengakibatkan kematian. Ciri-ciri kecanduan antara lain: kejang, sakit perut, badan gemetar, muntah-muntah, mata dan hidung berair, hilangnya nafsu makan dan hilangnya/berkurangnya berat badan.

Penggunaan narkoba dapat menghilangkan kesadaran pemakainya, menyebabkan paranoia (linglung), juga dapat membuat pemakainya menjadi ganas dan liar sehingga dapat mengganggu ketentraman di masyarakat. Untuk mendapatkan barang-barang haram itu, diperlukan tidak sedikit biaya, sehingga dapat menimbulkan perbuatan-perbuatan kriminal seperti pencurian, perampasan ataupun pertengkaran dan tidak sedikit pula yang menimbulkan pembunuhan.

Peredaran narkotika di Indonesia terindikasi dikendalikan jaringan internasional. Sebab hampir 70 persen narkotika yang beredar di dalam negeri merupakan kiriman dari luar negeri. Selain itu, kurangnya penegakan hukum menjadikan produsen narkotika luar negeri tertarik masuk ke Indonesia. Kebanyakan narkotika yang beredar di Indonesia berasal dari luar negeri. Negara pemasoknya kini mengalami pergeseran, asalnya dari ASEAN seperti Thailand, Birma, dan Laos. Kini meluas dari negara segitiga emas dunia, termasuk Kolumbia juga masuk ke Indonesia.

Hingga saat ini upaya yang paling efektif untuk mencegah penyalahgunaan narkoba bagi anak-anak yaitu dari pendidikan keluarga, masyarakat, dan lembaga-lembaga yang mengurusi masalah narkoba. Namun keluarga yang di harapkan dapat mengawasi dan mendidik anaknya untuk menjauhi narkoba.

\section{DAMPAK NARKOBA TERHADAP PERKEMBANGAN GENERASI MUDA}

Pemakaian narkoba pada akhir-akhir ini semakin marak seiring dengan kemajuan ilmu dan teknologi. Beberapa kasus dilaporkan pemakaian narkoba sebagian besar adalah pada usia remaja. Dan bahkan ada juga yang masih anak-anak. Hal ini karena pada usia ini merupakan usia untuk mencari identitas dan tingginya rasa ingin tahu sehingga sering coba-coba. Pemakaian narkoba pada tahap awal akan menyebabkan perasaan enak, tetapi pada pemakaian selanjutnya akan menimbulkan kerusakan organ tubuh. Kerusakan mental dan bahkan menyebabkan kematian. Jika pemakai narkoba tersebut adalah remaja atau bahkan anak-anak, maka akan berakibat rusaknya mental remaja sebagai generasi penerus bangsa. Rusaknya generasi penerus berakibat runtuhnya suatu bangsa/negara.

Narkoba adalah zat yang dapat menimbulkan pengaruh tertentu terhadap mereka yang menggunakannya dengan cara memasukkan obat tertentu ke dalam tubuhnya. Pengaruh tersebut berupa pembiasan, hilangnya rasa sakit, rangsangan, semangat dan halusinasi. Dengan timbulnya efek halusinasi inilah yang menyebabkan kelompok masyarakat terutama di kalangan remaja ingin menggunakan narkoba meskipun tidak menderita apaapa. Hal inilah yang mengakibatkan penyalahgunaan narkoba (obat). Bahaya menggunakan narkoba bila tidak sesuai dengan peraturan adalah adanya adiksi/ketergantungan obat (ketagihan).

Berdasarkan efek yang ditimbulkan terhadap pemakainya, narkoba dikelompokkan sebagai berikut:

- Halusinogen, yaitu efek dari narkoba bisa mengakibatkan seseorang menjadi ber-halusinasi dengan melihat suatu hal/benda yang sebenarnya tidak ada / tidak nyata bila dikonsumsi dalam sekian dosis tertentu. Contohnya kokain \& LSD.

- Stimulan, yaitu efek dari narkoba yang bisa mengakibatkan kerja organ tubuh seperti jantung dan otak lebih cepat dari biasanya sehingga mengakibatkan penggunanya lebih bertenaga serta cenderung membuatnya lebih senang dan gembira untuk sementara waktu. 
- Depresan, yaitu efek dari narkoba yang bisa menekan sistem syaraf pusat dan mengurangi aktivitas fungsional tubuh, sehingga pemakai merasa tenang bahkan tertidur dan tidak sadarkan diri. Contohnya putaw.

- Adiktif, yaitu efek dari narkoba yang menimbulkan kecanduan. Seseorang yang sudah mengonsumsi narkoba biasanya akan ingin dan ingin lagi karena zat tertentu dalam narkoba mengakibatkan seseorang cenderung bersifat pasif, karena secara tidak langsung narkoba memutuskan syaraf-syaraf dalam otak. Contohnya: ganja, heroin, dan putaw.

- Jika terlalu lama dan sudah ketergantungan narkoba maka lambat laun organ dalam tubuh akan rusak dan jika sudah melebihi takaran maka pengguna itu akan overdosis dan akhirnya mengakibatkan kematian.

Penggunaan narkoba dapat menghilangkan kesadaran pemakainya, menyebabkan paranoia (linglung), juga dapat membuat pemakainya menjadi ganas dan liar sehingga dapat mengganggu ketentraman di masyarakat. Untuk mendapatkan barang-barang haram itu, di perlukan tidak sedikit biaya, sehingga dapat menimbulkan perbuatan-perbuatan kriminal seperti pencurian, perampasan ataupun pertengkaran dan tidak sedikit pula yang menimbulkan pembunuhan.

Kesehatan fisik dan penampilan diri pengguna narkoba menurun dan suhu badan tidak beraturan, jalan sempoyongan, bicara pelo (cadel), apatis (acuh tak acuh), mengantuk, agresif, nafas sesak, denyut jantung dan nadi lambat, kulit terasa dingin, nafas lambat/berhenti, mata dan hidung berair, menguap terus menerus, diare, rasa sakit diseluruh tubuh, takut air sehingga malas mandi, kejang, kesadaran menurun, penampilan tidak sehat, tidak peduli terhadap kesehatan dan kebersihan, gigi tidak terawat dan kropos, terdapat bekas suntikan pada lengan atau bagian tubuh lain (pada pengguna dengan jarum suntik).

Di rumah, para pengguna narkoba membangkang terhadap teguran orang tua, tidak mau mempedulikan peraturan keluarga, mulai melupakan tanggung jawab rutin di rumah, malas mengurus diri, sering tertidur dan mudah marah, sering berbohong, banyak menghindar pertemuan dengan anggota keluarga lainnya karena takut ketahuan bahwa ia adalah pecandu, bersikap kasar terhadap anggota keluarga lainnya dibandingkan dengan sebelumnya, pola tidur berubah, menghabiskan uang tabungannya dan selalu kehabisan uang, sering mencuri uang dan barang-barang berharga di rumah, sering merongrong keluarganya untuk minta uang dengan berbagai alasan, berubah terhadap teman dan jarang mau mengenalkan teman-temannya, sering pulang lewat jam malam dan menginap di rumah teman, sering pergi ke disko, mall atau pesta, bila ditanya sikapnya defensive atau penuh kebencian, sekali-sekali dijumpai dalam keadaan mabuk.

Prestasi belajar pengguna narkoba di sekolah tiba-tiba menurun drastis, perhatian terhadap lingkungan tidak ada, sering kelihatan mengantuk di sekolah, sering keluar dari kelas pada waktu jam pelajaran dengan alasan ke kamar mandi, sering terlambat masuk kelas setelah jam istirahat; mudah tersinggung dan mudah marah di sekolah, sering berbohong, meninggalkan hobi-hobinya yang terdahulu (misalnya kegiatan ekstrakurikuler dan olahraga yang dahulu digemarinya), mengeluh karena menganggap keluarga di rumah tidak memberikan dirinya kebebasan, mulai sering berkumpul dengan anak-anak yang "tidak beres" di sekolah.

Penggunaan narkoba dapat menyebabkan efek negatif yang akan menyebabkan gangguan mental dan perilaku, sehingga mengakibatkan terganggunya sistem neuro-transmitter pada susunan saraf pusat di otak. Gangguan pada sistem neuro-transmitter akan mengakibatkan terganggunya fungsi kognitif (alam pikiran), afektif (alam perasaan, mood, atau emosi), psikomotor (perilaku), dan aspek sosial.

Selain hal-hali di atas, konsekuensi negatif dari penyalahgunaan narkoba pada remaja lainnya, mungkin mencakup:

1. Gangguan mengemudi. Mengemudi di bawah pengaruh obat apapun dapat mengganggu keterampilan pengemudi kendaraan bermotor, waktu reaksi dan penilaian menempatkan pengemudi, penumpangnya, dan lain-lain beresiko di jalan.

2. Aktivitas seksual. Remaja yang menyalahgunakan narkoba lebih mungkin untuk memiliki penilaian yang buruk, yang dapat menyebabkan seks yang tidak direncanakan dan tidak aman.

3. Ketergantungan obat. Remaja yang menyalahgunakan narkoba akan meningkatkan risiko ketergantungan obat yang serius di kemudian hari.

4. Gangguan konsentrasi. Penggunaan obat-obatan, seperti mariyuana, mungkin mempengaruhi memori remaja, motivasi dan kemampuan untuk belajar. 
5. Masalah kesehatan yang serius. Ekstasi dapat menyebabkan kerusakan hati dan gagal jantung. Dosis tinggi atau penggunaan kronis amfetamin dapat menyebabkan perilaku psikotik. Kronis penggunaan inhalansia dapat membahayakan jantung, paru-paru, hati dan ginjal. Penyalahgunaan resep obat atau over-the-counter dapat menyebabkan gangguan pernapasan dan kejang.

Narkoba merupakan obat yang bermanfaat dibidang kesehatan dan pengembangan ilmu pengetahuan, tetapi hal ini banyak disalahgunakan oleh masyarakat khususnya para remaja. Dampak yang di peroleh dari penyalahgunaan obat-obatan terlarang tersebut adalah sangat merugikan penggunanya. Pemakaian narkoba dapat menyebabkan ketergantungan yang hebat, sehingga dapat merusak organ-organ tubuh serta dapat menyerang saraf manusia. Hal ini membuat para penggunanya melakukan tindakan-tindakan yang dapat merusak perkembangan jati dirinya. Seorang remaja yang sudah kecanduan barang terlarang tersebut, akan selalu berusaha untuk mengkonsumsinya. Terkadang seorang pemakai narkoba tidak sadar telah melakukan perbuatan yang kurang baik karena terpengaruh obat-obatan tersebut. Sebagaian besar dampak narkoba itu dapat mengancam jiwa serta kesadaran remaja.

\section{KARAKTER}

Pembangunan karakter bangsa merupakan gagasan besar yang dicetuskan para pendiri bangsa karena sebagai bangsa yang terdiri atas berbagai suku bangsa dengan nuansa kedaerahan yang kental, bangsa Indonesia membutuhkan kesamaan pandangan tentang budaya dan karakter yang holistik sebagai bangsa. Pembangunan karakter bangsa bertujuan untuk membina dan mengembangkan karakter warga negara sehingga mampu mewujudkan masyarakat yang ber-Ketuhanan Yang Maha Esa, berkemanusiaan yang adil dan beradab, berjiwa persatuan Indonesia, berjiwa kerakyatan yang dipimpin oleh hikmat kebijaksanaan dalam permusyawaratan perwakilan, serta berkeadilan sosial bagi seluruh rakyat Indonesia. Karakter bangsa adalah kualitas perilaku kolektif kebangsaan yang khas baik yang tercermin dalam kesadaran, pemahaman, rasa, karsa, dan perilaku berbangsa dan bernegara sebagai hasil olah pikir, olah hati, olah rasa dan karsa, serta olah raga seseorang atau sekelompok orang.

Pembangunan karakter bangsa adalah upaya kolektif-sistemik suatu negara kebangsaan untuk mewujudkan kehidupan berbangsa dan bernegara yang sesuai dengan dasar dan ideologi, konstitusi, haluan negara, serta potensi kolektifnya dalam konteks kehidupan nasional, regional, dan global yang berkeadaban untuk membentuk bangsa yang tangguh, kompetitif, berakhlak mulia, bermoral, bertoleran, bergotong royong, patriotik, dinamis, berbudaya, dan berorientasi ipteks berdasarkan pancasila dan dijiwai oleh iman dan takwa kepada Tuhan Yang Maha Esa.

Karakter adalah istilah yang diambil dari bahasa Yunani yang berarti "menandai", yaitu menandai tindakan atau tingkah laku seseorang. Jadi, seseorang disebut berkarakter bila tingkah lakunya sesuai dengan kaidah moral. N.K. Singh dan Mr. A.R. Agwan (2000:175) menyatakan bahwa menurut bahasa, karakter adalah tabiat atau kebiasaan. Sedangkan menurut ahli psikologi, karakter adalah sebuah sistem keyakinan dan kebiasaan yang mengarahkan tindakan seorang individu. Karena itu, jika pengetahuan mengenai karakter seseorang itu dapat diketahui, maka dapat diketahui pula bagaimana individu tersebut akan bersikap untuk kondisi-kondisi tertentu.

Kata karakter tersebut memang sulit didefinsikan tapi banyak sekali pengertian seperti pendapat kedua tokoh yaitu Prof. Dr. H. M. Quraish Shihab dan Sigmund Freud. Menurut pendapat yang pertama yaitu" Himpunan pengalaman, pendidikan, dan lain-lain yang menghubungkan kemampuan di dalam diri kita, sebagai alat ukir sisi paling dalam hati manusia yang mewujudkan baik pemikiran, sikap, dan perilaku termasuk aktivitas mulia dan budi perkerti" dan yang kedua "Kumpulan tata nilai yang mewujud dalam suatu sistem daya juang yang melandasi pemikiran"

Menurut Suyanto dan Djihat Hasyim (2000), karakter adalah cara berpikir dan berperilaku yang menjadi ciri khas tiap individu untuk hidup dan bekerja sama, baik dalam lingkup keluarga, masyarakat, bangsa, dan negara. Individu yang berkarakter baik adalah individu yang bisa membuat keputusan dan siap mempertanggungjawabkan tiap akibat dari keputusan yang dibuatnya. Batasan lain dari karakter ialah "Charakter 
means the constellation of strengths and weaknesses that form and reveal who we are. Assessing our character means taking an inventory of our dominant thoughts and actions."

Karakter terdiri dari 3 komponen yang berhubungan satu sama lain, yaitu pengetahuan moral (moral knowing), perasaan moral (moral feeling), dan perilaku moral (moral behavior). Karakter yang baik terdiri dari pengetahuan tentang kebaikan (knowing the good), keinginan untuk berkebaikan (desiring the good), dan berbuat kebaikan (doing the good). Dalam hal ini dibutuhkan pembiasaan dalam pemikiran yang baik (habit of the good mind), pembiasaan dalam hati yang baik (habits of the good heart), dan pembiasaan berupa tindakan yang baik (habits of the action in good). Karakter seseorang berkembang berdasarkan potensi yang dibawa sejak lahir yang dikenal sebagai karakter dasar atau biologik, dan aktualisasi karakter dalam bentuk perilaku adalah sebagai hasil perpaduan antara karakter biologik dan hasil interaksi dengan lingkungannya.

Kertajaya sebagaimana dikutip Majid dan Andayani (2012:11) mendefinisikan bahwa karakter adalah "ciri khas" yang dimiliki oleh suatu benda atau individu. Ciri khas tersebut adalah "asli" dan mengakar pada kepribadian benda atau individu tersebut dan merupakan "mesin" pendorong bagaimana seorang bertindak, bersikap, dan merespon sesuatu. Berdasarkan pengertian karakter ini dapat dipahami secara gamblang bahwa karakter itu sama halnya dengan akhlak di dalam Islam. Karakter dapat dikatakan sebagai tindakan refleks yang dilakukan seseorang tanpa butuh perenungan dan pemikiran terlebih dahulu yang merupakan buah dari kebiasaankebiasaan terdahulu, baik itu kebiasaan baik maupun buruk. Kebiasaan tersebut berakumulasi hingga menjadi karakter.

Pada dasarnya karakter bukanlah hitungan matematis yang dapat diukur secara kuantitatif. Karakter adalah sifat-sifat kejiwaan yang membeda kan seseorang dengan orang lain. Karakter merupakan fase kedua dalam merepresentasikan kejiwaan manusia. Fase pertama ialah sifat, selanjutnya karakter, tabiat, dan watak. Menurut ilmu psikologi, sifat dan karakter bisa diubah sejauh pribadi/kelompok masyarakat tersebut mau untuk mengubahnya.

\section{MEMBENTUK GENERASI MUDA BERKARAKTER BEBAS NARKOBA}

Pembentukan karakter seorang anak, memang butuh waktu dan komitmen dari orangtua dan sekolah atau guru (jika memprioritaskan hal ini) untuk mendidik anak menjadi pribadi yang berkarakter. Butuh upaya, waktu dan cinta dari lingkungan yang merupakan tempat dia bertumbuh, cinta disini jangan disalah artikan memanjakan. Jika kita taat dengan proses ini maka dampaknya bukan ke anak kita, kepada kitapun berdampak positif. Paling tidak karakter sabar, toleransi, mampu memahami masalah dari sudut pandang yang berbeda, disiplin dan memiliki integritas (ucapan dan tindakan sama) terpancar di diri kita sebagai orangtua ataupun guru. Hebatnya, proses ini mengerjakan pekerjaan baik bagi orangtua, guru dan anak jika kita komitmen pada proses pembentukan karakter.

Rhonda Byrne (2007:17) menyatakan bahwa unsur terpenting dalam pembentukan karakter adalah pikiran, karena pikiran yang di dalamnya terdapat seluruh program yang terbentuk dari pengalaman hidupnya, merupakan pelopor segalanya. Program ini kemudian membentuk sistem kepercayaan yang akhirnya dapat membentuk pola berpikirnya yang bisa mempengaruhi perilakunya. Jika program yang tertanam tersebut sesuai dengan prinsip-prinsip kebenaran universal, maka perilakunya berjalan selaras dengan hukum alam. Hasilnya, perilaku tersebut membawa ketenangan dan kebahagiaan. Sebaliknya, jika program tersebut tidak sesuai dengan prinsip-prinsip hukum universal, maka perilakunya membawa kerusakan dan menghasilkan penderitaan. Oleh karena itu, pikiran harus mendapatkan perhatian serius.

Tentang pikiran, Joseph Murphy (2002:6) mengatakan bahwa di dalam diri manusia terdapat satu pikiran yang memiliki ciri yang berbeda. Untuk membedakan ciri tersebut, maka istilahnya dinamakan dengan pikiran sadar (conscious mind) atau pikiran objektif dan pikiran bawah sadar (subconscious mind) atau pikiran subjektif. Pikiran sadar yang secara fisik terletak di bagian korteks otak bersifat logis dan analisis dengan memiliki pengaruh sebesar $12 \%$ dari kemampuan otak. Sedangkan pikiran bawah sadar secara fisik terletak di medulla oblongata yang sudah terbentuk ketika masih di dalam kandungan. Karena itu, ketika bayi yang dilahirkan menangis, bayi tersebut akan tenang di dekapan ibunya karena dia sudah merasa tidak asing lagi dengan detak jantung ibunya. Adi W. Gunawan (2005:27) menegaskan bahwa pikiran bawah sadar bersifat netral dan sugestif. 
Untuk memahami cara kerja pikiran, kita perlu tahu bahwa pikiran sadar (conscious) adalah pikiran objektif yang berhubungan dengan objek luar dengan menggunakan panca indra sebagai media dan sifat pikiran sadar ini adalah menalar. Sedangkan pikiran bawah sadar (subsconscious) adalah pikiran subjektif yang berisi emosi serta memori, bersifat irasional, tidak menalar, dan tidak dapat membantah. Kerja pikiran bawah sadar menjadi sangat optimal ketika kerja pikiran sadar semakin minimal.

Ariesandi Setyono (2006:50) menyatakan secara alami, sejak lahir sampai berusia tiga tahun, atau mungkin hingga sekitar lima tahun, kemampuan menalar seorang anak belum tumbuh sehingga pikiran bawah sadar (subconscious mind) masih terbuka dan menerima apa saja informasi dan stimulus yang dimasukkan ke dalamnya tanpa ada penyeleksian, mulai dari orang tua dan lingkungan keluarga. Dari mereka itulah, pondasi awal terbentuknya karakter sudah terbangun. Pondasi tersebut adalah kepercayaan tertentu dan konsep diri. Jika sejak kecil kedua orang tua selalu bertengkar lalu bercerai, maka seorang anak bisa mengambil kesimpulan sendiri bahwa perkawinan itu penderitaan. Tetapi, jika kedua orang tua selalu menunjukkan rasa saling menghormati dengan bentuk komunikasi yang akrab maka anak akan menyimpulkan ternyata pernikahan itu indah. Semua ini akan berdampak ketika sudah tumbuh dewasa.

Selanjutnya, semua pengalaman hidup yang berasal dari lingkungan kerabat, sekolah, televisi, internet, buku, majalah, dan berbagai sumber lainnya menambah pengetahuan yang akan mengantarkan seseorang memiliki kemampuan yang semakin besar untuk dapat menganalisis dan menalar objek luar. Mulai dari sinilah, peran pikiran sadar (conscious) menjadi semakin dominan. Seiring perjalanan waktu, maka penyaringan terhadap informasi yang masuk melalui pikiran sadar menjadi lebih ketat sehingga tidak sembarang informasi yang masuk melalui panca indera dapat mudah dan langsung diterima oleh pikiran bawah sadar.

Semakin banyak informasi yang diterima dan semakin matang sistem kepercayaan dan pola pikir yang terbentuk, maka semakin jelas tindakan, kebiasan, dan karakter unik dari masing-masing individu. Dengan kata lain, setiap individu akhirnya memiliki sistem kepercayaan (belief system), citra diri (self-image), dan kebiasaan (habit) yang unik. Jika sistem kepercayaannya benar dan selaras, karakternya baik, dan konsep dirinya bagus, maka kehidupannya akan terus baik dan semakin membahagiakan. Sebaliknya, jika sistem kepercayaannya tidak selaras, karakternya tidak baik, dan konsep dirinya buruk, maka kehidupannya akan dipenuhi banyak permasalahan dan penderitaan

Terdapat empat sifat karakter yang dirasa sangat penting dan berpengaruh terhadap perbaikan bangsa ini, yaitu kejujuran, kedisiplinan, sportifitas dan toleransi terhadap perbedaannya. Pada kenyataaanya sifat karakter ini sudah jarang kita temui yang kokoh mempertahankan nilai. Oleh karena itu hendaknya kita semua bersama-sama mulai membenahi kondisi bangsa saat ini. Dimulai dari diri sendiri, hal yang kecil dan sekarang juga. Jika nilai karakter bangsa sudah kembali kita miliki, bukan tidak mungkin bangsa ini akan menjadi besar ditataran dunia dan disegani karena berkarakter.

Secara garis besarnya, yang menjadi perhatian orang tua, guru, dan orang dewasa lainnya dalam membentuk generasi muda berkarakter bebas narkoba, adalah perlakuan yang diberikan pada anak-anak dan para remaja. Mendidik anak dengan penuh cinta dan kasih sayang, pengertian dan pemahaman yang baik, akan menimbulkan perasaan diterima. Dalam menghadapi tingkah laku remaja, bersabarlah, bersikaplah jujur, kembangkan toleransi dan menghargai, sehingga tertanamkan kepercayaan dalam diri mereka. Hindari emosi negatif dalam menghadapi tingkah laku remaja yang di luar dugaan

Pada masa remaja yang penuh gejolak, rasanya patut kalau orang tua memprogram pikiran anak dengan prinsip kebenaran universal. Anak sedini mungkin diperkenalkan dengan norma dan peraturan yang berlaku. Tegakkan kedisiplinan yang tegas dalam membentuk tingkah laku anak. Anak adalah karunia Tuhan yang penuh dengan keunikan, tuntutan untuk menjadi sempurna dan tanpa salah, rasanya tidak mungkin diberlakukan kepada anak. Oleh karena itu, patut rasanya anak mendapatkan penerimaan yang tulus dari orang tua atas keadaan dan kondisi dirinya.

Menciptakan komunikasi yang akrab dan terbuka, merupakan sebuah terobosan yang dapat dilakukan untuk mengendalikan tingkah laku anak. Berusaha untuk selalu ada saat anak membutuhkan, terutama ketika mereka menemukan persoalan dengan dunia luar. Bersedia mendengarkan keluhan anak dan berbagi dengan mereka, akan mempererat hubungan emosional dengan para remaja. Membantu anak untuk mampu membuat 
tameng agar dirinya tidak terkontaminasi oleh pergaulan yang tidak sehat di lingkungan. Memandirikan anak agar mampu memanfaatkan pengalaman yang didapatkan dari lingkungan untuk menghadapi kehidupan real

Memperlihatkan kehidupan keluarga yang harmonis, akrab, saling menunjang dan menguatkan, akan menciptakan keadaan emosional yang menenangkan bagi anak. Dengan kondisi yang demikian, anak akan mampu menemukan identitas diri yang positif dan bisa terhindar dari bahaya mematikan narkoba. Hal yang paling penting adalah, memperkenalkan anak dengan Tuhan YME sedini mungkin. Mengenal Tuhan akan membuat anak memiliki kontrol sendiri atas tingkah lakunya. Anak akan berusaha menjauhi semua yang dilarang oleh Tuhan dan menjalankan apa yang diperintahkan Tuhan. Karena anak yang telah dibiasakan dengan tindakan yang dibolehkan dan yang harus dihindarkan, akan mampu mengendalikan dirinya dari hal-hal negatif yang akan merugikan dirinya termasuk narkoba. Sebab anak-anak yang demikian telah menyadari tentang adanya dosa dan pahala.

Pembangunan karakter anak sangat ditentukan olehpola asuh sejak dini dalam keluarga. Karena itu perlu dibangun keluarga yang kokoh untuk dapat melahirkan generasi-generasi penerus yang berkualitas ,berkarakter kuat yang bermanfaat besar dalam masyarakat. Yang harus berperan bukan hanya ibu, tetapi juga ayah. Bahkan keterlibatan ayah dalam pengasuhan dimasa kecil sampai usia remaja sangat menentukan pembentukan karakter anak. Keluarga yang harmonis, dimana ayah dan ibu saling berinteraksi dengan kasih sayang akan memberikan suatu lingkungan yang kondusif bagi pembentukan karakter anak

Cara tersebut dapat menanamkan karakter remaja termasuk para pelajar dan mahasiswa. Lalu tanamkan nilai-nilai seperti nilai agama, nilai sosial, nilai budaya dan nilai pendidikan kepada seluruh pelajar dan mahasiswa itu untuk memberikan contoh yang baik kepada kita seperti pelajar dan generasi muda. Membangun karakter bukan hanya tugas generasi muda, untuk itu perlu kedisiplinan tinggi bagi seluruh komponen dengan upaya menyiapkan kondisi, sarana/prasarana, kegiatan, pendidikan, dan pembiasaan serta kasih sayang yang mengarah kepada pembentukan watak dan budi pekerti generasi muda bangsa.

\section{PEMANFAATAN MODEL KONSELING DALAM PEMBENTUKAN GENERASI MUDA BERKARAKTER BEBAS NARKOBA}

Ada banyak alasan anak mengkonsumsi narkoba, diantaranya, tidak memiliki rasa percaya diri ataupun kurang mendapat kasih sayang orang tua dapat menyebabkan timbulnya penyalahgunaan narkoba di kalangan remaja. Jika seorang anak di tempatkan pada lingkungan yang berhubungan dengan narkoba, maka sulitlah bagi kalangan tersebut untuk mengubah pengaruhnya, terlebih lagi jika lingkungan itu sangat kuat mempengaruhi anak tersebut. Kurangnya kesadaran beragama dan informasi yang positif serta bermanfaat bagi para remaja. Memiliki banyak persoalah hidup yang tidak mampu dipecahkan sendiri dan tidak memiliki orang-orang yang peduli untuk berbagi. Mudahnya akses untuk mendapatkan narkoba juga menjadi alasan para remaja untuk mencoba-coba. Beberapa hal di atas, merupakan penyebab anak atau remaja terjerumus ke lembah narkoba.

Sebagaimana diketahui bahwa konseling adalah upaya konselor terhadap klien atau sekelompok klien agar ia dapat keluar dari masalah yang dihadapi, sehingga dapat berperilaku secara efektif dalam kehidupan sehari- hari. Konseling yang dilakukan konselor harus menempuh prosedur yang jelas, agar proses yang terjadi lebih menjadi efektif dan tepat sasaran. Untuk itu Prayitno (2002) berpendapat bahwa konseling bukan sematamata rumusan kalimat verbal,tetapi juga memuat tentang peran yang diemban oleh konselor dan klien, prosedur yang ditempuh, dan perilaku klien yang akan diubah dalam proses tersebut. Karena itu untuk memberikan layanan kepada klien setidak- tidaknya terdapat beberapa model-model (pendekatan) yang digunakan oleh konselor. Model-model (pendekatan) tersebut memiliki karakteristik tersendiri, demikian halnya dengan keterbatasan dan keunggulannya.

Model-model (pendekatan) tersebut juga dapat dimanfaatkan untuk membantu membentuk karakter generasi muda bebas narkoba. Pemanfaatan model-model (pendekatan) tersebut, patut untuk dipraktekkan oleh konselor untuk membantu para remaja agar memiliki karakter yang diharapkan. Penggunaan model-model (pendekatan) dalam praktek konseling menuntut keberanian, kesadaran, dan kebijaksanaan yang integritas serta sistematis yang tertuang dalam layanan. Konseling diperlukan oleh semua individu yang tidak berperilaku efektif 
dalam kehidupan sehari- hari. Berikut Pemanfaatan model-model (pendekatan) dalam konseling untuk membantu membentuk karakter generasi muda bebas narkoba :

\section{Konseling Psikoanalisis Klasik (Kopsak)}

Menurut kopsak, individu bermasalah karena ketidaksesuaian dan ketidakefektifan antara kerja id, ego dan super ego. Ketidaksesuaian dan ketidakefektifan ini dapat dilihat dari tingkah laku yang dimunculkan individu tersebut. Hal ini dapat terjadi ketika, keinginan dari id, dipenuhi oleh ego tanpa pertimbangan super ego, sehingga terjadi pelanggaran atas norma atau aturan yang membuat individu bermasalah. Kejadian itu akan menimbulkan kecemasan pada diri individu. Jika penanganannya tidak tepat, bukan tidak mungkin individu ini akan lari ke narkoba.

Selain itu, permasalahan pada diri individu menurut kopsak juga bisa terjadi karena, proses belajar pada masa kanak-kanak yang tidak sesuai atau tidak benar. Anak terlalu banyak mendapat tekanan atau indoktrinasi dengan nilai-nilai yang amat kaku. Hal ini dapat mempengaruhi perkembangan kepribadian, karena menimbulkan konflik-konflik dalam diri sendiri. Dimana jika merasa telah terlalu mentok, anak mengambil jalan pintas yang salah.

Agar permasalahan tersebut tidak berlanjut dan menimbulkan kerusakan permanen pada diri individu, maka perlu penanganan yang tepat. Dalam kondisi bermasalah seperti yang dikemukakan dalam kopsak ini, para individu bermasalah butuh untuk dipahami dan dimengerti. Oleh karena itu, agar mereka tidak terjerumus ke jurang kelam narkoba, maka menurut kopsak yang dapat dilakukan konselor adalah, mendengarkan semua yang mereka curahkan dalam sesi konseling. Hal ini dilakukan agar mereka merasa di dengar dan akan menimbulkan efek dipahami pada diri individu tersebut. Untuk membina tingkah laku individu ke arah yang lebih baik, maka konselor perlu menafsirkan hasil konseling. Hasil penafsiran dari konselor inilah nantinya yang akan dijadikan rujukan oleh klien, untuk memperbaiki tingkah lakunya dan menjauhkan diri dari bahaya narkoba.

\section{Konseling Ego (Konego)}

Menurut konego individu bermasalah karena individu kehilangan kemampuan atau tidak diperkenankan merespon rangsangan dari luar secara tepat, sehingga pada saat sekarang menjadi salah tingkah. Anak-anak yang dikekang dengan aturan nilai-nilai yang kaku, jika dibiarkan sedikit longgar, maka ia anak mempergunakannya untuk hal-hal yang menurutnya menarik, termasuk narkoba. Selain itu, bila pola coping behavior yang sudah terbina pada dirinya, tidak sesuai lagi dengan tempat dia berada sekarang. Stress karena kebiasaannya dianggap ganjil oleh masyarakat tempat tinggalnya yang baru juga memungkinkan mereka untuk menenangkan diri dengan cara menggunakan narkoba. Hal berikutnya yang menimbulkan masalah pada diri individu adalah, tidak berjalannya dengan baik salah satu, salah dua atau ketiga dari fungsi ego. Maka individi tidak mampu lagi mempertimbangkan baik buruk tingkah lakunya.

Agar individu tersebut tidak terlalu larut dalam permasalahannya, maka yang dapat dilakukan konselor menurut konego adalah, membina hubungan akrab dengan klien. Setelah terbina keakraban yang baik antara konselor dan klien, klienpun sudah merasa nyaman bersama dengan konselor. Maka hal berikutnya yang perlu diperbaiki oleh konselor adalah membentuk coping behavior yang dikehendaki sesuai dengan lingkungan dan situasi. Kemudian membantu memfungsikan ego klien kembali sebagaimana semestinya.

\section{Konseling Psikologi Individual (Kopsin)}

Menurut kopsin individu bermasalah karena feeling of inferiority, apalagi jika keadaannya diperparah dengan cacat fisik atau mental, perlakuan orang tua yang tidak wajar dan bila diterlantarkan. Dalam keadaan yang demikian, akan sangat besar kemungkinan individu akan mengembangkan gaya hidup yang keliru dengan cara memakai narkoba. Hal ini terjadi karena individu memiliki konsep diri yang negatif. Dimana anak menghayati dirinya jauh dari keadaan yang dimilikinya sekarang, sehingga menghambat hubungan sosialnya. Jika anak telah 
menjauh dari lingkungan sosialnya, maka bukan mustahil anak akan lebih dekat dengan narkoba. Maka untuk menghindari hal ini terjadi, konselor menurut kopsin harus mampu membantu klien mengembangkan tujuan hidup yang lebih membahagiakan dan merancang suatu gaya hidup yang lebih konstruktif. Dalam hal ini yang dapat dilakukan konselor adalah, lebih mendorong klien melakukan hubungan sosial yang bermanfaat, dan menghindarkan diri dari kehancuran yang dinamakan narkoba.

\section{Konseling Analisis Transaksional (Konsistran)}

Dalam konsistran, ketika individu memilih posisi hidup devolusioner, revolusioner atau obvolusioner, mereka memposisikan dirinya pada posisi not OK. Kemudian kecenderungan menggunakan ego state tunggal, cair dan tercemar, juga membuat individu berada dalam kondisi bermasalah untuk berhubungan dengan lingkungan. Pada keadaan yang demikian, dalam melakukan hubungan sosial individu sering merasa dirinya tidak berarti dan tidak mampu memanfaatkan ego state yang tepat dalam berinteraksi dengan orang lain. Maka mereka yang demikian cenderung tidak dapat diterima dalam berhubungan sosial. Untuk menenangkan diri dan merasa sedikit nyaman, maka individu tersebut bisa saja terjerumus ke lembah narkoba.

Agar hal tersebut tidak terjadi, maka peran konselor dalam model ini adalah membantu klien memahami sifat dan jenis transaksi mereka dengan orang lain ketika melakukan transaksi. Konselor membantu klien menghilangkan pencemaran ego. Membantu klien agar dapat mempergunakan ego state adult secara optimal. Membebaskan klien dari ketidakstabilan posisi hidup, dengan sedikit pencerahan pada klien. Diharapkan klien bisa menempatkan diri pada posisi saya OK kamu OK dalam berinteraksi dengan siapapun. Hal ini diupayakan untuk meminimalisir kemungkinan individu lari ke narkoba.

\section{Konseling Self (Konself)}

Individu akan menunjukkan tingkah laku yang berbeda-beda dalam menghadapi lingkungan. Berdasarkan tingkah laku yang ditunjukkan itulah orang-orang dilingkungan memberikan penilaian kepada individu. Ada individu yang mampu menanggapi dengan baik penilaian tersebut, karena dia memiliki konsep yang baik tentang dirinya. Ada juga individu yang menerima mentah-mentah penilaian dari lingkungan tersebut, tanpa melihat potensi yang ada pada dirinya. Oleh karena itu muncullah ketidakseimbangan dan ketidaksesuaian dalam diri individu tersebut. Hal ini menyebabkan individu berada dalam kondisi cemas yang berkepanjangan dan mempertahankan diri walaupun tingkah lakunya tidak tepat. Orang seperti ini biasanya cenderung mdah dipengaruhi dan diajak untuk menggunakan narkoba.

Jika keadaan di atas terjadi pada klien, maka yang dapat dilakukan konselor untuk membantu antara lain adalah membebaskan diri klien dari kungkungan tingkah laku yang palsu selama ini. Membantu klien menumbuhkan kepercayaan diri, memberikan kesempatan untuk percaya pada orang lain dan mempersepsi lingkungan dengan baik, karena lingkungan adalah bagian hidup. Menjelaskan kepada klien bahwa dia adalah manusia yang berkembang dan mampu beraktualisasi. Oleh karena itu konselor diharapkan membebaskan klien dari beban psikologisnya dan bisa beraktualisasi dengan baik tanpa pengaruh narkoba.

\section{Konseling Behavioral (Konbe)}

Individu dalam kehidupannya, agar mampu melakukan berbagai hal, maka mereka melakukan aktivitas yang disebut juga dengan belajar. Melalui proses belajar inilah terbentuk kebiasaan dalam diri individu. Ada kebiasaan yang dapat diteriam lingkungan dan ada pula kebiasaan yang tidak dapat diterima oleh lingkungan. Sementara individu dalam kehidupannya, harus menyesuaikan tingkah laku yang dipelajari dengan tuntutan lingkungan. Jika hal tesebut tidak terjadi, maka individu akan mengalami permasalahan dalam kehidupannya di lingkungan tersebut. Mereka akan dibicarakan, akan diberi label negatif, dan cenderung akan dijauhi oleh lingkungan. Dalam kondisi seperti inilah individu rentan untuk berhubungan dengan narkoba.

Konselor dalam hal ini akan berfungsi sebagai guru bagi klien, yang akan mengajari mereka berbagai hal yang dapat diterima lingkungan. Konselor harus mampu memberikan penguatan, agar klien cenderung mengulang 
tingkah lkau yang dikehendaki. Dalam proses konseling inilah konselor membantu klien menciptaka kondisikondisi baru melalui proses belajar di bawah bantuan konselor. hal ini dilakukan agar klien menguasai tingkah laku baru yang efektif dan dapat diterima di tengah masyarakat, sehingga individu ini dapat diterima dan terhindar dari pengaruh jahat narkoba.

\section{Konseling Rasional Emotif (Korem)}

Individu dianugrahi kemampuan berpikir logis dan tidak logis, kemampuan berpikir rasional dan irrasional. Perkembangan pikiran rasional dan logis akan membawa individu dalam kehidupan berpandangan real dan masuk akal. Namun tidak sedikit pula individu yang memiliki pikiran yang irrasional, sehingga mereka tidak tenang dalam menjalani hidup. Menurut korem, gejala gangguan kepribadian pada manusia berupa neurosis atau psikosis yang bersumber dari sikap dan cara-cara berpikir yang irrasional atau illogis, baik terhadap diri sendiri maupun lingkungannya. Hal ini akan mengganggu emosional yang cenderung merusak, mengganggu, serta menyalahkan diri sendiri dengan pola perilaku yang negatif. Jika hal ini dibiarkan, untuk membuat mereka merasa tenang, individu akan memanfaatkan obat-obatan terlarang. Dalam hal ini, konselor diharapkan bisa membantu memperbaiki dan merobah sikap, persepsi, cara berpikir, keyakinan serta pandangan-pandangan klien yang irrasional dan illogis menjadi rasional dan logis. Hal ini dilakukan agar klien dapat mengembangkan diri, meningkatkan aktualisasi diri seoptimal mungkin melalui perilaku kognitif dan afektif yang positif. Selain itu, konselor juga diharapkan membantu menghilangkan gangguan emosional yang merusak dan merugikan diri sendiri. Jika hal tersebut telah tercapai, diharapkan individu tersebut dapat memiliki minat diri, minat sosial, arahan diri, toleransi, fleksibelitas, penerimaan diri, komitmen, berpikir ilmiah, dan dapat menerima kenyataan dengan baik. Kondisi yang seperti ini dapat menjauhkan individu dari pengaruh narkoba.

\section{Konseling Realitas (Koreal)}

Kebutuhan adalah sesuatu yang mutlak dan harus dipenuhi oleh setiap individu dalam kehidupannya. Pemenuhan kebutuhan dilakukan agar individu tetap bisa bertahan hidup. Apabila individu tidak mampu memenuhi kebutuhannya, ia akan kehilangan hubungan dengan kenyataan, persepsinya tentang kenyataan menjadi kacau. Kebutuhan yang menjadi inti dari koreal ini adalah, kebutuhan untuk dicintai dan mencintai. Jika kebutuhan ini tidak terpenuhi, maka individu cenderung bertingkah laku yang bersifat negatif. Bahkan tentu tidak terkecuali mereka ini akan lari ke narkoba.

Konselor dalam hal ini harus hangat, sensitif, dan memiliki kemampuan untuk memahami tingkah laku. Konselor harus menjadi kuat dan tidak memaafkan tindakan klien yang merugikan orang lain. Hal ini dilakukan agar klien dapat bertanggung jawab.

\section{Konseling Gestalt (Konges)}

Individu yang kurang menyadari tentang dirinya sendiri dan lingkungan, kurang bertanggung jawab terhadap diri dan lingkungan, kehilangan kontak dengan lingkungan, menolak kebutuhan diri sendiri, tidak mampu menyelesaikan masalah secara meyeluruh dan menempatkan diri sebagai orang yang sangat hebat atau sangat tidak berharga. Hal-hal di atas menunjukkan individu yang bermasalah menurut konges. Banyak hal yang terjadi dalam kehidupan individu yang membuat individu merasakan hal-hal yang demikian. Bila individu tersebut dibiarkan, maka mungkin saja hal-hal negatif yang akan menenangkan diri merekalah yang mereka cari, diantaranya adalah narkoba.

Klien yang demikian sangat membutuhkan suasana yang memungkinkan klien dapat menampilkan diri, membuka diri dan berusaha mengenal diri dan lingkungannya dengan lebih baik. Oleh karena itu, mereka membutuhkan orang-orang yang benar-benar mampu mengerti dan memahami mereka. Dengan keadaan yang demikianlah mereka akan berusaha menyeimbangkan keinginan mereka dengan lingkungan. Tentu saja lingkungan yang mereka harapkan adalah lingkungan yang juga mampu menerima mereka deengan baik. Ketika 
memerak telah merasa nayaman dengan situasi tersebut, maka mereka akan mendapat kemungkinan untuk mengembangkan diri mereka dengan baik dan tentu saja jauh dari narkoba.

\section{PENUTUP}

Salah satu yang meresahkan masyarakat tak hanya di Indonesia tapi juga di seluruh penjuru dunia adalah peredaran narkoba, terutama di kalangan pelajar. Tak hanya mengkonsumsi, dewasa ini bahkan ada juga pelajar dan generasi muda yang membantu pengedarannya, mulai dari menjadi bandar hingga kurir yang mengantar narkoba dari satu tempat ke tempat lainnya. Penyalahgunaan narkoba merupakan salah satu masalah sosial yang senantiasa muncul ditengah-tangah masyarakat. Ini sama halnya dengan penyakit masyarakat lainnya seperti perjudian, pelacuran, pencurian, dan pembunuhan yang sulit diberantas atau bahkan sepertinya tidak bisa dihapuskan sama sekali.

Peredaran narkoba kian hari kian mengkhawatirkan. Negeri ini, sudah dalam keadaan yang memprihatinkan karena peredaran narkoba yang ada. Sama seperti korupsi, narkoba juga menjadi salah satu pembunuh karakter bangsa. Indonesia sedang berada dalam krisis karakter. Generasi muda cenderung kehilangan orientasi dan karakter diri untuk mereka menjalani hidupnya. Hal ini juga disebabkan karena timbulnya pengaruh negatif yang menimbulkan egoisme yang tidak di imbangi dengan keseriusan. Upaya pencegahan penyebaran narkoba di kalangan generasi muda sudah seharusnya menjadi tanggung jawab kita bersama, dalam hal ini semua pihak termasuk orang tua, guru, dan masyarakat harus turut berperan aktif dalam mewaspadai ancaman narkoba terhadap anak-anak kita. Diharapkan upaya ini juga dapat membantu memperbaiki karakter dan moral generasi muda penerus bangsa.

Salah satu cara yang dapat ditempuh untuk membentuk dan memperbaiki karakter generasi muda adalah dengan pemberian bantuan konseling. Konseling yang dilakukan konselor harus menempuh prosedur yang jelas, agar proses yang terjadi lebih menjadi efektif dan tepat sasaran. Konseling bukan semata- mata rumusan kalimat verbal, tetapi juga memuat tentang peran yang diemban oleh konselor dan klien, prosedur yang ditempuh, dan perilaku klien yang akan diubah dalam proses tersebut. Karena itu untuk memberikan layanan kepada klien setidak- tidaknya terdapat sembilan model konseling yang digunakan oleh konselor. Kesembilan model konseling tersebut memiliki karakteristik tersendiri, demikian halnya dengan keterbatasan dan keunggulannya. Pemberian bantuan pelayanan konseling dengan menggunakan sembilan model konseling ini, diharapkan menjadi salah satu alternatif dalam membantu membentuk karakter generasi muda yang bebas narkoba.

\section{DAFTAR PUSTAKA}

Adi W. Gunawan. (2005). Hypnosis - The Art of Subconscious Communication. Jakarta: PT Gramedia Pustaka Utama.

Ariesandi Setyono. (2006). Hypnoparenting: Menjadi Orangtua Efektif dengan Hipnosi. Jakarta: PT. Gramedia Pustaka Utama.

Dadang Hawari, dkk. (2002). Penyalahgunaan dan Ketergantungan NAPZA. Jakarta: UI Press.

Departemen Sosial RI. (2004). Pedoman bagi tenaga konselor dalam penyelahgunaan NAPZA. Jakarta: Direktorat PRSKN.

Furqon, Hidayatullah. (2010). Pendidikan Karakter Membangun Peradaban Bangsa. Yuma Pustaka : UNS Press.

Gary W.Lawson. (1996). Essentials of Chemical Dependency Counseling. California: Aspen Publishers, Inc.

Gibson, Robert L and Mitchell, Marianne H. 2011. Bimbingan dan Konseling (Alih Bahasa: Yudi Santoso) Yogyakarta: Pustaka Pelajar.

Hurlock, Elizabeth. (1980). Psikologi Perkembangan Suatu Pendekatan Sepanjang Rentang Kehidupan. Jakarta: Erlangga. 
Jeffrey A. Kottler. (1996). Introduction to Therapetic Counseling. Australia: Brooks/Cole Publishing Company. Joseph Murphy D.R.S. (2002). Rahasia Kekuatan Pikiran Bawah Sadar. Jakarta: Spektrum.

N.K. Singh dan Mr. A.R. Agwan. (2000). Encyclopaedia of the Holy Qur'ân. New Delhi: Balaji Offset

Rhonda Byrne. (2007). The Secret. Jakarta: PT Gramedia Pustaka Utama.

Suyanto dan Hisyam, Djihad. (2000). Pendidikan di Indonesia Memasuki Milenium III: Refleksi dan Reformasi. Yogyakarta: Adicita Karya Nusa.

Taufik. (2009). Model-Model Konseling. Padang: UNP Press. 